\title{
Time response of FOPID controlled PV based cascaded landsman converter-inverter fed induction motor and electric drives applications
}

\author{
R. Pazhanimurugan ${ }^{1}$, R. Bensraj ${ }^{2}$, C. R. Balamurugan ${ }^{3}$ \\ ${ }^{1,2}$ Faculty of Engineering and Technology, Annamalai University, India \\ ${ }^{3}$ Department of Electrical Engineering, Karpagam College of Engineering, India
}

\begin{tabular}{|c|c|}
\hline Article Info & ABSTRACT \\
\hline Article history: & Time Response enhancement utilizing photovoltaic based cascaded \\
\hline Received Sep 25, 2019 & $\begin{array}{l}\text { Landsman Converter (LC) structure is one of the soft strategies in the recent } \\
\text { scenario. The prime function of a DC-DC Landsman converter is to optimize }\end{array}$ \\
\hline Revised Dec 15, 2019 & the output power of the photovoltaic array and reduce the output voltage \\
\hline Accepted Feb 16, 2020 & $\begin{array}{l}\text { ripples. This paper reveals the demonstration and simulation of the Cascaded } \\
\text { Landsman Converter Inverter System (CLCIS) with a PV source. MATLAB }\end{array}$ \\
\hline Keywords: & $\begin{array}{l}\text { Simulink-model for CLCIS has been created utilizing the components of } \\
\text { Simulink and closed-loop examinations are performed with PI and }\end{array}$ \\
\hline $\begin{array}{l}\text { CLCIS } \\
\text { FOPID } \\
\text { LC }\end{array}$ & $\begin{array}{l}\text { Fractional-Order-PID (FOPID) Controllers. The present work deal with the } \\
\text { comparison of transient and steady-state time responses of CLCIS with PI } \\
\text { and FOPID controllers. The outcomes demonstrate that dynamic reaction is } \\
\text { enhanced by utilizing FOPID controller. }\end{array}$ \\
\hline
\end{tabular}

Photovoltaic array

PI

This is an open access article under the $\underline{C C B Y-S A}$ license.

PWM

Voltage regulation

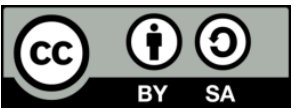

\section{Corresponding Author:}

R. Pazhanimurugan,

Faculty of Engineering and Technology,

Annamalai University,

Chidambaram, India.

Email: rpmuruganmail@gmail.com

\section{INTRODUCTION}

Regular Buck, Boost and Buck-Boost converters are not reasonable for low and medium voltage Induction motor drive applications. In addition, these DC-DC converters not appropriate for power factor improvement, consistent yield voltage and to decrease harmonic mutilation. Three propelled topologies, to be specific SEPIC, Zeta, and Landsman Converters (LCs) are prescribed to limit the disadvantages of these essential DC-DC converters. These converters work on Buck-Boost mode dependent on load prerequisites.

Singh and Bist proposed a BL-CSC converter works in DICM for DC link voltage control to control the speed of the electrical drives [1]. Williams proposed three sorts of DC-DC converters, each type with three quantities of buck, lift and buck-support voltage configurations that offer ceaseless vitality flow and yield vitality stream necessary for non-regular vitality source, MPPT and greatest source vitality extraction $[2,3]$. Landsman suggests a canonical changing cell from which the three essential DC-DC converter topologies energy can be derived [4]. Barry clarified the fundamental ideas of all fundamental mono-switch, dual-state, DC-DC voltage sourced converters, by duality, as nonexclusive related current and voltagesourced converters [5]. Leonhard set forward that as opposed to DC drives, there is a decision of a wide range of blends of intensity converters and AC machines, each having specific advantages [6]. Anjanee Kumar Mishra and Bhim Singh concentrated on the proposition and usage of an effective and ease photovoltaic generator-based water siphoning framework including a switched reluctance motor drive [7]. 
MATLAB Simulink based examination and correlation of SEPIC, Landsman, and Zeta converters for PV took care of induction motor drive applications are completed in [8]. Partial Order PID Controlled PV BuckBoost Converter with Coupled Inductor topology was executed for unadulterated DC load. Durgadevi and Karthick actualized the fragmentary order PID controller for yield voltage control of DC-DC Zeta converter [9]. Field-direction control using complex TF work to tune the PI-controller is introduced in [10, 11]. The PI controller associated with the IM direct torque control has been shown by [12]. To improve the execution characteristics of the motor when worked with variable repeat supplies, it is required to control voltage [13]. Usually, the PI controller is used for controlling the drive. PI gathers botch, making a significant overshoot in the speed response which, in the most cynical situation, could even unbalance out the structure; a marvel is known as Windup [14]. Comparison among PI and FOPID controlled PV took care of buck help converter with coupled inductor framework for DC load was implemented [15]. FOPID controller design procedures and transfer function successive approximation and optimization techniques are presented by Rasoanarivo [16]. Sathya and Arounassalame suggested a partial order PID controller for the Soft Switched Boost converter in [17]. Fragmentary order displaying has pulled in the consideration of researchers and designers in the field of control system plan $[18,19]$. Time response analysis was done for PI and Fuzzy Logic controlled SEPIC converter based resonant inverter took care of induction warming system [20]. R. Duma, P. Dobra, and M. Trusca implemented a FOPID controller for DC motor control with five parameters tuning [21]. The single-phase-engines are generally connected to single-phase electrical framework for electrical home gadgets, for-example, centrifugal-pump, electric-fan, air-blower, etc while the three-phase induction motors are typically connected to a three-phase electrical framework for mechanical applications like the prime-mover inline creation framework because of their moderately ease, free support \&high unwavering quality [22][23]. The IM can be utilized for a steady speed when the recurrence of the voltage source is a consistent. Due to the advancement of power electronics by producing a three-phase supply of variable frequency and voltage with PWM systems, speed control is realized. [24]. Induction engine drives are discovered applications in transportation and electric trains, family apparatuses, paper, and material ventures, rolling and concrete factories, siphons, blowers, lift, transports, smashers, machine instruments, and mechanical technology, and so on. As per Electric Power Research Institute, USA, practically $60 \%$ to $65 \%$ of energy is devoured by electric engine drives in which $75 \%$ of electrical engine drives are siphon, fan, and blower type drives. The greater part of the siphons and fans in businesses are utilized for liquid stream control [25].

Cascaded LC has gained more importance due to its voltage regulation capability and power quality improvement characteristics. To exploit the advantages of a landsman converter, the investigation was done for a suitable controller. In this scenario, combining the advantages of the combination of LC and FOPID controllers, a novel method is proposed to improve the voltage regulation and time-domain specifications of LC output to feed the VSI which drives the most popular electrical drive known as IM. In this paper, a FOPID controlled cascaded LC to improve the transient response is proposed. The study results in better voltage regulation reduced ripples and improved time response specifications. The productive utilization of PV exhibit and constraining the high starting inrush current in the engine drive is the prime assignment of an LC.

\section{DESIGN AND PRINCIPLE OF LANDSMAN CONVERTER}

A Landsman Converter (LC) is one of the topologies of a DC-DC buck-support converter, able to defeat the confinement of recently utilized converters in a photovoltaic array. This converter is determined by a Canonical Switching Converter (CSC) or topological changes on a DC-DC boost converter. The adjustment in CSC with a yield-inductor, consequences in an LC. The output and input currents have broad current undulation which is a disadvantage of the CSC converter. In the expansion of a little inductance at the yield of this transformation stage leads to a certified switched-mode topology. CSC has astounding execution capacity as a power factor pre-regulator. A blend of switch SW1, capacitor C2, and diode D3 is known as a 'canonical switching cell' and this cell joined with an inductor L2 and a DC interface capacitor C4 is identified as a CSC converter. Among different DC-DC converters, LC meets the ideal execution of the framework contrasted with other converters. The conventional buck-boost converter has the most minimal number of segments; however, it yields high current ripples. The proposed LC has a critical component that the input current ripples and yield current ripples are low.

The continuous conduction mode of operation is also to be achieved in LC by the appropriate design of the components. Depending on the ecological factors the operation of the converter is in boost or buckmode. A schematic diagram of PV connected with the landsman appears in Figure 1. 


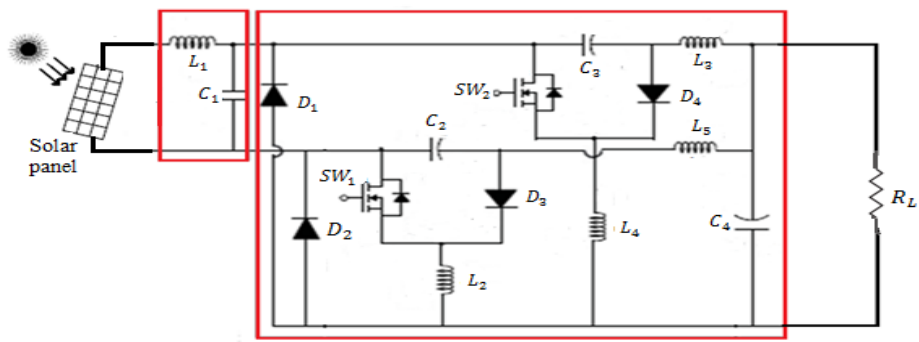

Figure 1. A schematic diagram of landsman converter with PV source

The value is the yield voltage of LC and the input voltage is from sun oriented PV array is obtained as the Vmpp. The various parameters such as input inductor L1, output inductor L2, DC-link capacitor C1, and intermediate capacitor $\mathrm{C} 2$ of the $\mathrm{LC}$ are designed. The following values are considered for simulation work and it is shown in Table-1.

$$
\begin{aligned}
& L_{1}=\frac{M * I_{0}}{8 * f^{2} * C_{1} * \Delta I_{L_{1}}} \\
& L_{2}=\frac{M * V_{P V}}{f * \Delta I_{L_{1}}} \\
& C_{1}=\frac{M * I_{0}}{f * \Delta V_{C_{1}}}
\end{aligned}
$$

Table 1. Simulation parameters

\begin{tabular}{ll}
\hline $\mathrm{V}_{\text {in }}$ & $200 \mathrm{v}$ \\
\hline $\mathrm{C}_{1}$ & $2500 \mu \mathrm{F}$ \\
$\mathrm{L}_{1}$ & $0.5 \mathrm{mH}$ \\
$\mathrm{C}_{2}, \mathrm{C}_{3}$ & $0.3 \mu \mathrm{F}$ \\
$\mathrm{C}_{4}$ & $0.1 \mu \mathrm{F}$ \\
$\mathrm{L}_{2}$ & $1 \mathrm{mH}$ \\
MOSFET(IRF840) & $500 \mathrm{~V} / 8 \mathrm{~A}$ \\
DIODE & $230 \mathrm{~V} / 1 \mathrm{~A}$ \\
$\mathrm{~V}_{0}$ & $415 \mathrm{~V}$ \\
\hline
\end{tabular}

\section{DESCRIPTION OF THE PROPOSED SYSTEM}

The LC supplies the Voltage Source Inverter which drives the IM coupled with the centrifugal pump. The output of the PV cluster is increased utilizing LC. The boosted DC is given to a PWM inverter. The LC is another alternative for directing an unregulated input power supply, similar to a minimal effortwall-wart. LC-based power factor rectifier as appeared in Fig-1 is intended to work in continuous conduction mode for dynamic characteristic control at landsman converter voltage. In contrast with Zeta, LC gives better execution for the IM drive application. Three operating phases of a PV based LC are explained in this section.

Mode I: When the switch-SW1 is ON, vitality from the supply and stored vitality in the middle of the road capacitor C2 are transferred to enter inductor L2. The yield inductor L5 begins releasing and the voltage of the middle capacitor $\mathrm{C} 2$ begins diminishing while DC-connect voltage across $\mathrm{C} 4$ begins rising. The designing value of the middle capacitor is sufficiently huge to store required vitality with the end goal that the voltage across the capacitor doesnot get discontinuous.

Mode II: In this method of converter activity, the switch is turned off. A transitional capacitor C2 and DC-link side inductor L5 are charging through the supply current while yield inductor L2 begins releasing. Hence, the voltage across $\mathrm{C} 2$ starts increasing in this mode. Moreover, the voltage across the DC capacitor $\mathrm{C} 4$ decreases.

Mode III: This is the DCM for converter operation as the enter inductor L2 is released totally and the current through L2 gets zero. The current through DC bus side inductor L5 begins rising and the voltage of the middle capacitor $\mathrm{C} 2$ keeps on diminishing in this mode. The cascaded output of the converter is given to VSI. The VSI fed IM pumping system is given in Figure 2. 


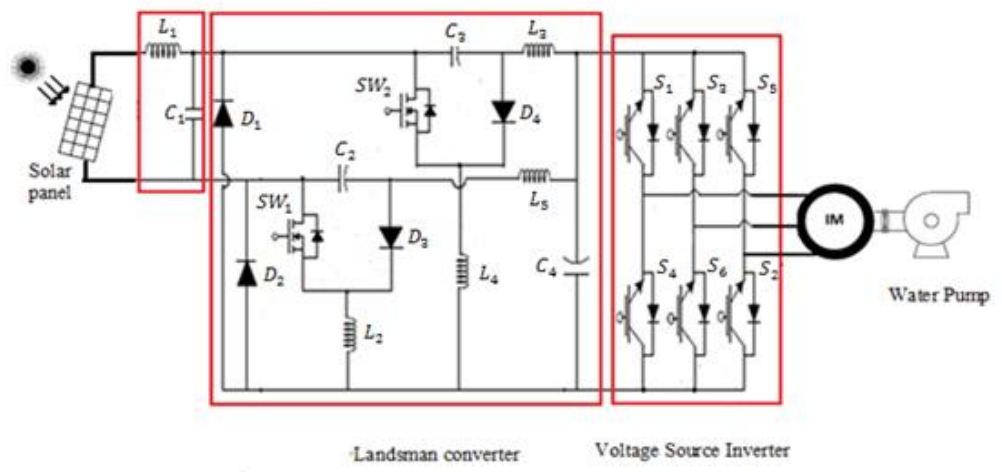

Figure 2. PV based Landsman Converter fed Induction Motor Pumping System

As of late, it has been shown that fragmentary order differential conditions can depict the conduct of some demonstrable dynamical systems superior to their whole number order counterparts. Using fragmentary order displaying, a summarized variation of the customary PID controllers, known as FO-PID is proposed. The augmentation of the traditional PID controller is the FOPID controller. The PID controller has three parameters that can be changed to tune the controller, while the FOPID controller has five parameters. Therefore, higher adaptability and better shut circle execution can be accomplished utilizing a FOPID controller. Fragmentary order calculus is utilized in a wide scope of science and engineering fields and furthermore in the field of control frameworks.

The TF of fragmentary order controller is communicated as beneath.

$$
G_{s}(S)=K_{P}+\frac{K_{i}}{S^{2}}
$$

$\mathrm{Kp}, \mathrm{Ki}, \mathrm{Kd}$ are proportional, integral, derivative gains respectively for traditional PID controllers whereas the FOPID controller has two additional parameters namely, integral $\operatorname{order}(\lambda)$ and differential $\operatorname{order}(\mu)$.With the two additional parameters, the FOPID can be spoken to as the general order of the PID and extends it from point to plan and includes greater adaptability and more precision in framework control. The plan parameters, for example, $\mathrm{Kp}, \mathrm{Ki}$, and $\mathrm{Kd}$ are gotten through the Zeigler-Nichols technique for the whole number order PID controller are utilized in this FOPID controller. The extra parameters for example noninteger order of integrator and differentiator are picked utilizing experimentation strategy to get the optimum outcome.

\section{SIMULATION RESULTS AND DISCUSSION}

\subsection{LC with PI controller}

Circuit-diagram of closed-loop-control of of landsman converter with induction motor drive with PIcontroller is delineated in Figure 3.

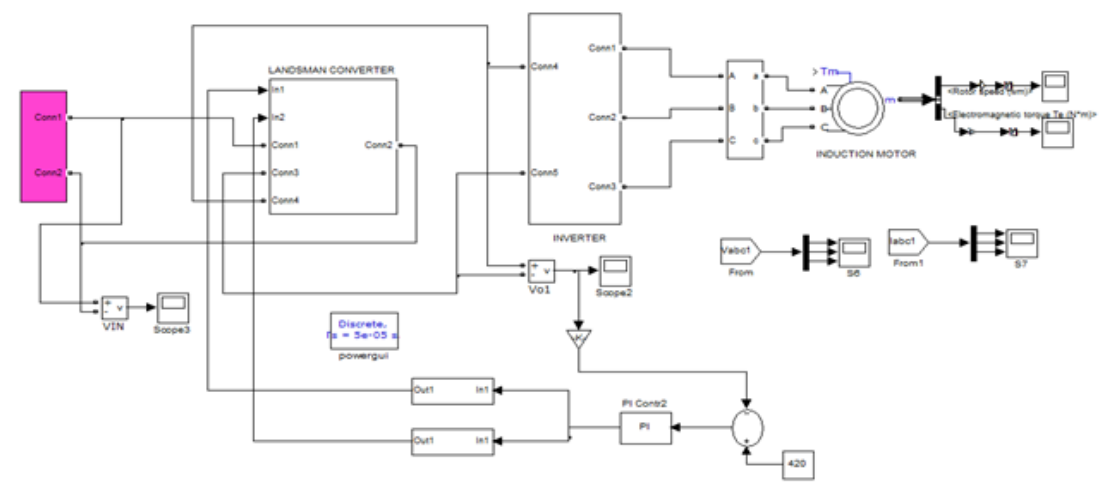

Figure 3. Circuit diagram of PV based LC with induction motor drive with PI controller 
Voltage across PV panel is delineated in Figure 4 and its value is 220V. Voltage across the landsman converter is delineated in Figure 5 and its value is $420 \mathrm{~V}$.

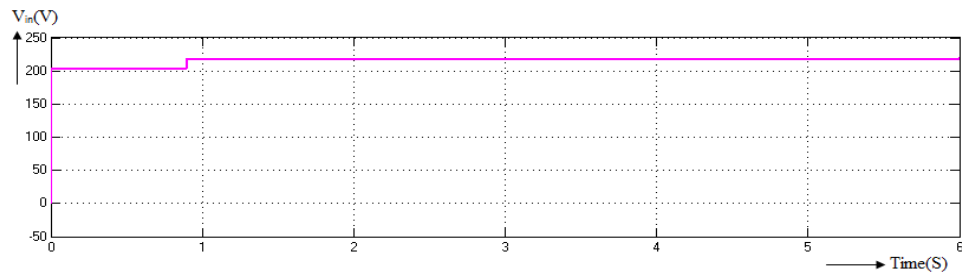

Figure 4. Voltage across PV Panel

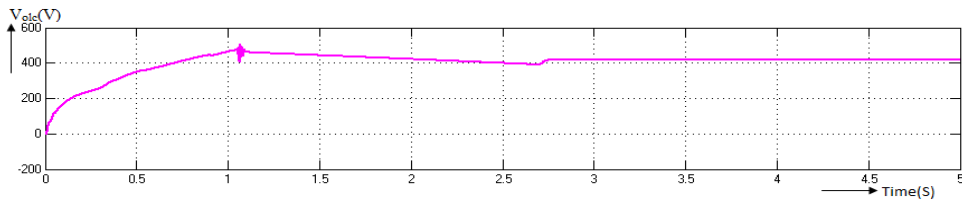

Figure 5. Voltage across landsman converter

Voltage across the inverter is delineated in Figure 6.

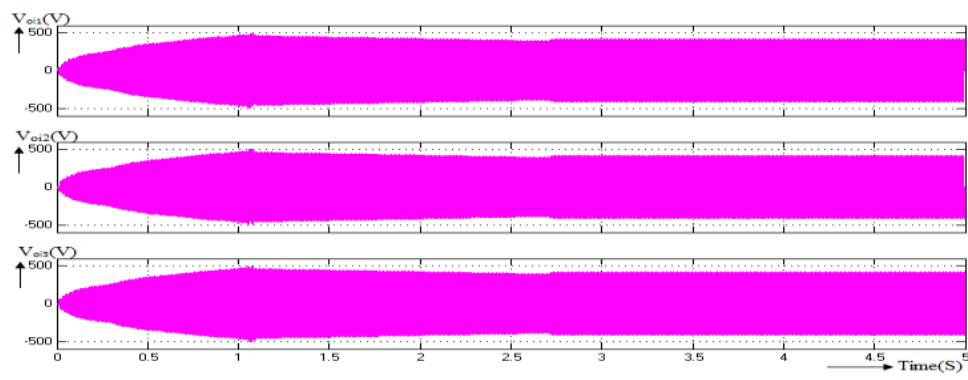

Figure 6. Voltage across inverter

The Induction motor-speed generation curve is delineated in Figure 7 and it is settled after 2.65sec and the speed of the motor is 1299rpm. Torque is delineated in Figure 8 and its value is $2.6 \mathrm{Nm}$.

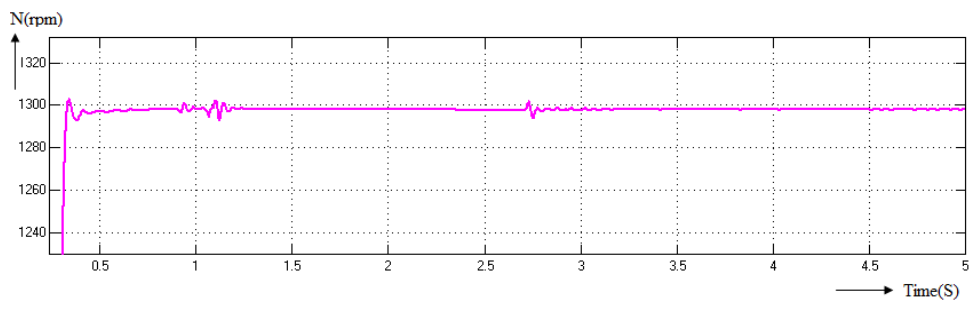

Figure 7. Motor speed 


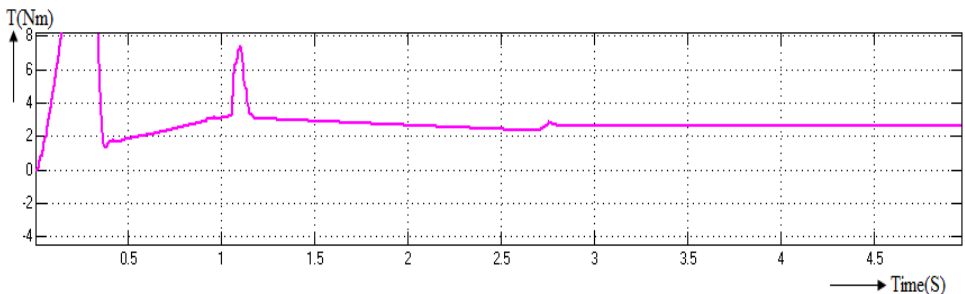

Figure 8. Motor torque

\subsection{LC with FOPID controller}

The LC took care of the induction motor is examined at consistent irradiance of $1000 \mathrm{w} / \mathrm{m}$ condition. The LC framework is planned by utilizing the parameters of Table. 1 and its yield voltage is assessed in the Time domain platform utilizing MATLAB Simulink-model. The transient and steady-state time-domain response of the projected FOPID controller is assessed and contrasted with the PI controller. The benefits of partial order controllers are exploited to improve the dynamical time response. They are less sensitive to alterations in the parameters of a controlled framework and to alterations in the parameters of the controller itself. The Circuit-outline of closed-loop control of LC with IM drive with the FOPID controller is depicted in Figure 9.

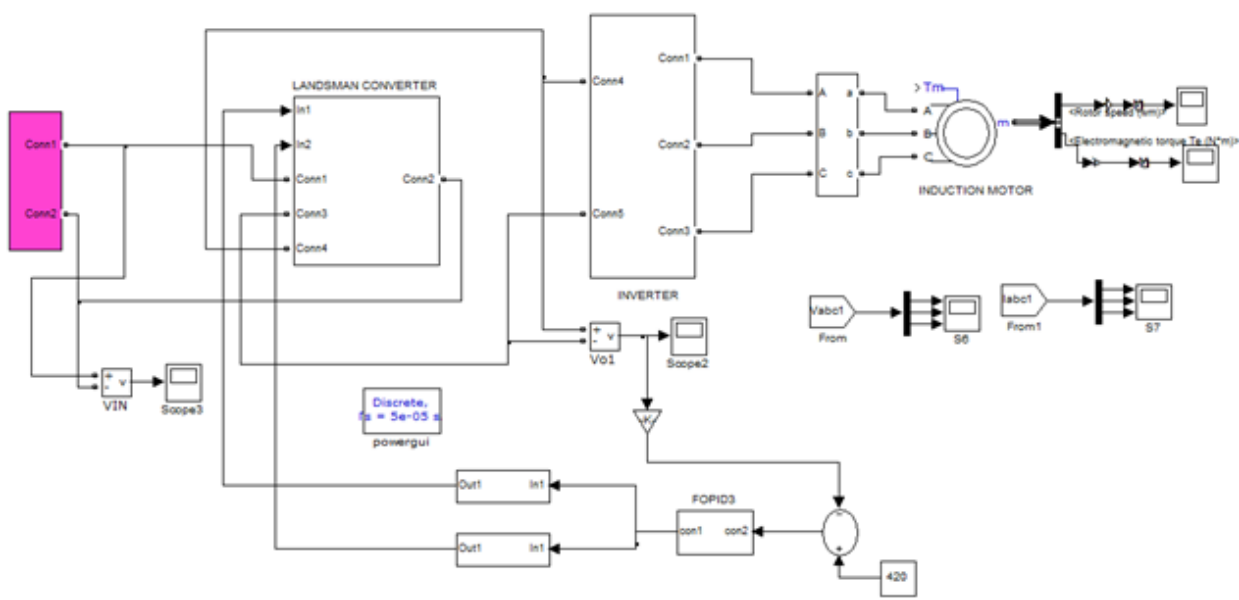

Figure 9. Circuit diagram of PV based LC with induction motor drive with FOPID controller

The yield of the PV panel is given as a contribution to the LC with induction motor drive is appeared in Figure 10 and its worth is $220 \mathrm{~V}$. The yield voltage across the proposed LC is portrayed in Figure 11 and its worth is $420 \mathrm{~V}$. Smooth control of DC connect voltage is gotten with restricted overshooting supply shows the dynamic conduct of the proposed framework. Figure 12 shows the voltage across the inverter. The Induction motor-speed generation curve is delineated in Figure 13 and it is settled after 2.00sec and the speed of the motor is $1300 \mathrm{rpm}$. Torque is shown in Figure 14 and its worth is $2.6 \mathrm{Nm}$.

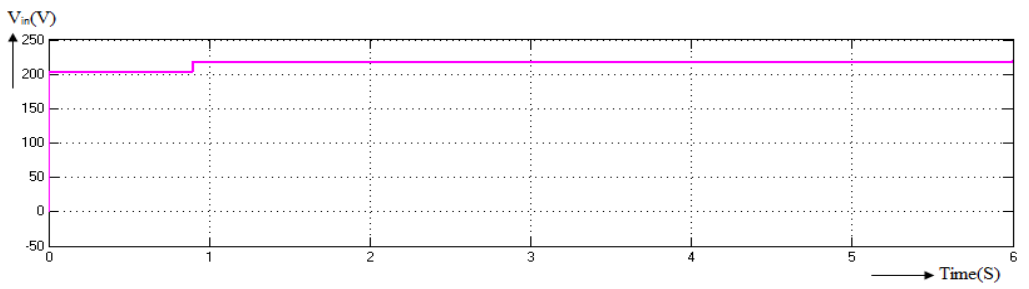

Figure 10. Voltage across PV panel 


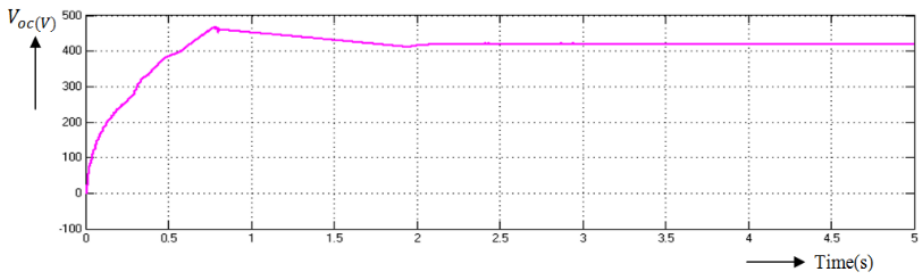

Figure 11. Voltage across LC

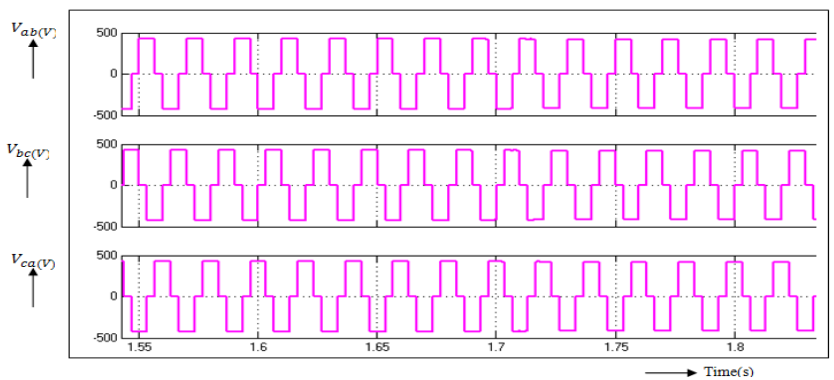

Figure 12. Voltage across Inverter

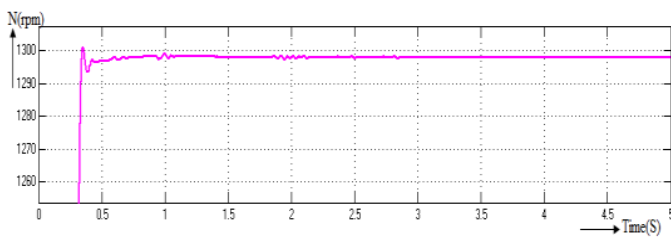

Figure 13. Motor speed

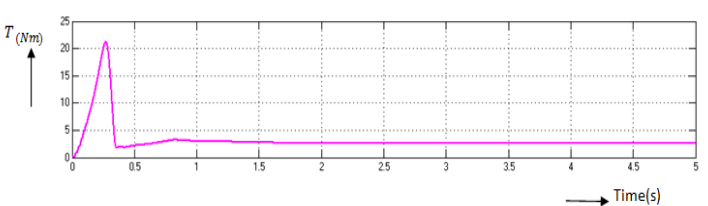

Figure 14. Motor torque

Figure 15 shows a comparison chart of time-domain parameters with PI and FOPID controllers. By utilizing FOPID controller it is seen that the 'ascent time' is decreased from $0.99 \mathrm{sec}$ to $0.97 \mathrm{sec}$; 'settling-time' is reduced from $2.65 \mathrm{sec}$ to $2.00 \mathrm{sec}$; 'peak time' is reduced from $1.10 \mathrm{sec}$ to $1.00 \mathrm{sec}$; 'steady state-error' is decreased from $1.9 \mathrm{~V}$ to $1.5 \mathrm{~V}$

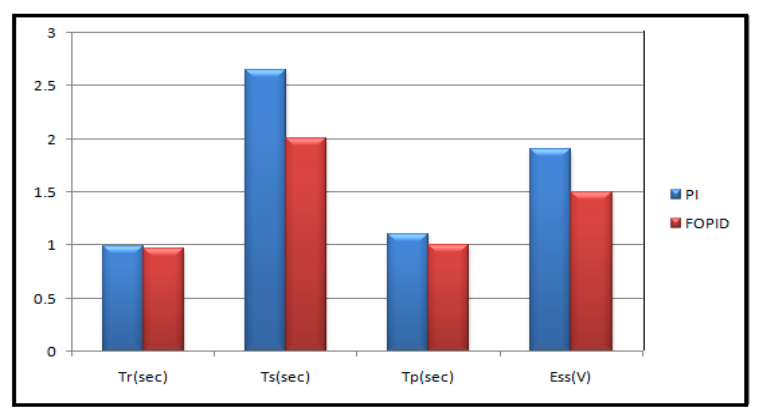

Figure 15. Comparison of Time-Domain-Parameters with PI and FOPID Controllers

\section{CONCLUSION}

Open-loop disturbance CLCIS, closed-loop voltage regulation CLCIS with PI, and FOPID controllers are modeled and simulated results are introduced. The analysis indicated that FOPID controlled CLCIS system gives improved time response. The analysis and simulation show that constant voltage and

Time response of FOPID controlled PV based cascaded landsman converter ... (R. Pazhanimurugan) 
constant speed can be maintained by using FOPID. The outcome represents that the FOPID controlled system is having low steady-state error and settling time. The benefits of the proposed framework are better speed response and high voltage gain.

\section{REFERENCES}

[1] B. Singh and V. Bist, "A BLCSC converter-fed BLDC motor drive with power factor correction", IEEE Trans. Ind. Electron., vol. 62, no. 1, pp. 172-183, Jan. 2015.

[2] B. W. Williams, "Basic DC-DC Converters", IEEE Trans. Power Electron. vol. 23, no. 1, pp. 387-401, Jan.2008.

[3] B. W. Williams, "DC-DC Converters with continuous input and output power", IEEE Trans. Power Electron. vol. 28, no. 5, pp. 2307-2316, May 2013.

[4] Landsman, 'A unifying derivation of switching DC-DC converter topologies', in 1979 IEEE Power Electronics Specialists Conference, San Diego, CA, USA, pp. 239-243, 1979.

[5] Barry W. Williams, 'Generation and analysis of canonical switching cell DC-DC converters', IEEE Trans. Ind. Electron., vol. 61, no. 1, pp. 329-346, Jan. 2014.

[6] W. Leonhard, 'Controlled AC drives, a Successful transfer from ideas to Industrial Practice,' Control Engineering Practice, vol.4, no.7, pp. 897-908, 1996.

[7] K. Mishra and B. Singh, 'Solar PV powered SRM driven water pumping system using Landsman converter', in 2016 IEEE International Conference on Power Electronics, Drives and Energy Systems (PEDES), Trivandrum, India, pp. 1-6, 2016.

[8] H. Basha, C. Rani, and S. Odofin, 'Analysis and Comparison of SEPIC, Landsman and Zeta Converters for PV Fed Induction Motor Drive Applications', in 2018 International Conference on Computation of Power, Energy, Information and Communication (ICCPEIC) of Power, Chennai, India, pp. 327-334, 2018.

[9] K. Durgadevi and R. Karthik, 'Performance Analysis of Zeta Converter Using Classical PID and Fractional Order PID Controller', in 2018 International Conference on Power, Energy, Control and Transmission Systems (ICPECTS), Chennai, pp.312-317, 2018.

[10] Briz, F., degener, M.W.\&Lorenz, R. D, “Analysis \& design of current regulators using complex vectors”, IEEE Transactions on Ind.Applications.vol. 32, pp. 817-825, 2000.

[11] Novotny, D.W \& Lipo, T.A. "Vector control \& dynamics of AC Drives", Clarendon Press, OXFORD.

[12] Xue, Y., Xu, X., Habetler, T.G. \& Divan, D.M "A low cost stator flux-oriented voltage source variable speed drive", Conference Record of the 1990 IEEE Industry Applications Society Annual Meeting, pp. 410-415, 1990.

[13] Collins, Edward Randolph."Torque \& slip behavior of single-phase induction motor driven from variable frequency supplies" Industry Applications, IEEE Trans, 28.3.1992: 710-715.

[14] Ba Thunya, AliS., et al."Single phase induction motor drives, a literature survey." IEEE International Electric Machines and Drives Conference (Cat. No.01EX485), IEMDC 2001.

[15] Vanitha. D and M. Rathinakumar, 'Fractional Order PID Controlled PV Buck-Boost Converter with Coupled Inductor', International Journal of Power Electronics and Drive Systems (IJPEDS), vol. 8, no. 3, pp. 1401-1407, Sep. 2017.

[16] Rasoanarivo, K. Arab-Tehrani, and F.-M. Sargos, 'Fractional Order PID and Modulated Hysteresis for high performance current control in multilevel inverters', in 2011 IEEE Industry Applications Society Annual Meeting, Orlando, FL, USA, pp. 1-7, 2011.

[17] Sathya and M. Arounassalame, 'Control of Soft Switched Boost Converter using Fractional order controller', in 2018 International Conference on Recent Trends in Electrical, Control and Communication (RTECC), Malaysia, pp. 204-209, 2018.

[18] PodlubnyI. 'Fractional order systems \& PI $\lambda$ D $\mu$ controllers', IEEE T Automat Controllers, pp.208-213, 1999.

[19] PodlubnyI, DorcákL, KostialI. 'On fractional derivatives, fractional order dynamic systems \& PI $\lambda$ D $\mu$ controllers. in: -36 th IEEE Conf., on Decision \& Control, SanDiego, CA, USA, pp.10-12, Dec.1997.

[20] Muthu Periyasamy, Chandrahasan Umayal, 'Improved Time Responses of PI and FL controlled SEPIC Converter based Series Resonant Inverter fed Induction Heating System', International Journal of Power Electronics and Drives System, vol.9, no 1, pp 305-315, March 2018

[21] DumaR, DobraP, TruscaM, 'Embedded application of fractional order control', Electronics Letters, vol. 48, pp. 1526-1528, 2012.

[22] M.Sulaiman, F. A. Patakor \& Z. Ibrahim, "DSP based implementation of field-oriented control of three phase induction motor drive", International Journal of Research in Engineering and Technology, Vol. 02, no. 09, pp. 179-186, 2013

[23] Azuwien Aida Bohari, Wahyu Mulyo Utomo, Zainal Alam Haron, Nooradzianie Muhd. -Zin, Sy Yi Sim, -Roslina Mat Ariff, "Speed tracking of indirect field-oriented control induction motor using neural network", Science Direct, Procedia Technology, vol. 11, pp. 141-146, 2013

[24] A. W. Leedy, "Simulink/MATLAB dynamic induction motor model for use as teaching- \& research tool", International Journal of Soft Computing and Engineering (IJSCE), Vol. 3, No. 4, pp-102-107, 2013.

[25] D. Sri Vidhya and T. Venkatesan, 'Quasi-Z-Source Indirect Matrix Converter Fed Induction Motor Drive for Flow Control of Dye in Paper Mill', IEEE Trans. Power Electron., vol. 33, no. 2, pp. 1476-1486, Feb. 2018. 


\section{BIOGRAPHIES OF AUTHORS}
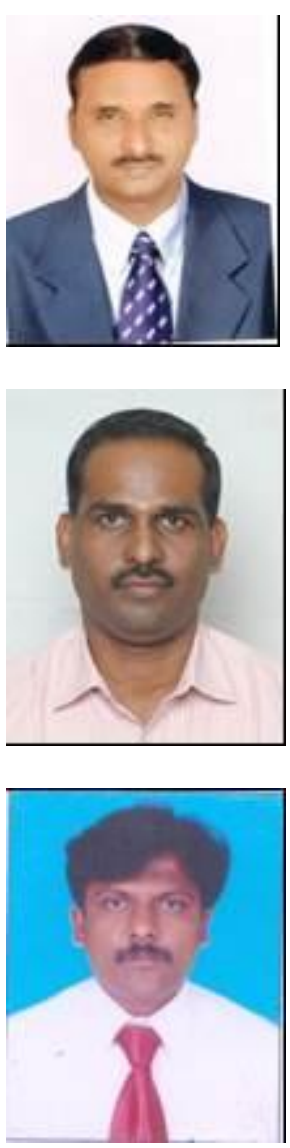

Mr. R. Pazhanimurugan received his B.E degree in Electrical and Electronics Engineering from Amrita Institute of Technology, Coimbatore. He has completed his post graduation in Power Electronics and Drives at SRM University, Chennai. He has been working as Assistant Professor at Arasu Engineering College, Kumbakonam, India since June 2013. Currently, he is pursuing Ph.D. at Annamalai University in the domain of PV based landsman converter with induction motor drives. He has six publications in international journals and presented many papers in various national and international conferences. His research interests include control and analysis of power converters and inverters, solar power systems, HVDC, hybrid systems.

R. Bensraj was born in 1973 in Marthandam. He has obtained B.E(Electrical Electronics and Power) and M.E (Power Systems) from Dr.Babasaheb Ambedkar Marathwada University, Maharashtra and Annamalai University respectively and then Ph.D in Power Electronics from Annamalai University, Chidambaram in 2011. He is currently working as Associate Professor in the Department of Electrical Engineering, Annamalai University where he has put in ninteen years of service. He produced four Ph.Ds and presently guiding three Ph.D Scholars and so far guided twelve M.E students. He has eighty publicaions in national, international journals and conferences. His fields of interest include multilevel inverter, power quality and Power electronics in power systems and also in image processing.

Dr. C.R. Balamurugan was born in 1978 in Kumbakonam. He has obtained B.E (Electrical and Electronics), M.E (Power Electronics and Drives) and Ph.D (Instrumentation EngineeringPower Electronics) degrees in 2000, 2005 and 2015 respectively from Arunai Engineering College, Tiruvannamalai, Sathyabama University, Chennai and Annamalai University, Chidambaram. He has been working in the teaching field for about 14 years. His areas of interest include power electronics, electrical machines and solar energy systems. He has 110 publications in international journals. His research papers 80 have been presented in various/IEEE international/national conferences. Currently, he is working as Professor and Head in the Department of EEE, Karpagam College of Engineering, Coimbatore. He is guiding $7 \mathrm{Ph} . \mathrm{D}$ scholars under Anna university, Chennai. He got Best Faculty Awards for nearly five times. He wrote more than thirty books. He is the reviewer for many reputed journals. He is a life member of Instrument Society of India and Indian Society for Technical Education. He is a member in IEEE. He cleared NPTEL certification Course. Received "DIGITAL GURU AWARD AND CASH PRIZE" for valuable contributions towards the digital content developed for Power Electronics 